\title{
Profil Pasien Infeksi Virus Dengue pada Anak di RSUD Sekadau Kabupaten Sekadau Provinsi Kalimantan Barat
}

\author{
Triswi Widyanti Mugi Raharjanti* Henry Alpius, ${ }^{* *}$ Husnia Auliyatul Umma, ${ }^{*}$ Rustam Siregar* \\ *Departemen Ilmu Kesehatan Anak Fakultas Kedokteran UNS Surakarta/RSUD Dr. Moewardi, Surakarta, ${ }^{* *}$ RSUD Sekadau, \\ Kabupaten Sekadau, Kalimantan Barat
}

\begin{abstract}
Latar belakang. Terdapat kenaikan kasus infeksi dengue siklus 10 tahunan dengan morbiditas dan mortalitas yang tinggi di RS Sekadau, Kalimantan Barat yang berbatasan dengan negara Malaysia.

Tujuan. Menggambarkan profil pasien infeksi virus dengue berupa manifestasi klinis, distribusi jenis kelamin, kelompok usia, dan musim.

Metode. Penelitian deskriptif dengan subyek pasien anak dengan infeksi virus dengue yang dirawat di RSUD Sekadau Kabupaten Sekadau Provinsi Kalimantan Barat April 2014-Maret 2015.

Hasil. Di antara 359 pasien anak dengan infeksi virus dengue didapatkan 41 menderita demam dengue, 306 menderita demam berdarah dengue (DBD), dan 12 menderita sindrom syok dengue (SSD). Jumlah pasien laki-laki 182 dan perempuan 177, kelompok usia 0-5 tahun 132 dan usia $>5$ tahun-18 tahun 227 pasien. Pada musim kemarau terjadi 90 kasus dan penghujan 269 kasus. Semua kasus menunjukkan hasil pemeriksaan NS1 positif.

Kesimpulan. Kasus terbanyak adalah DBD pada laki-laki dengan kelompok terbanyak usia $>5$ tahun-18 tahun pada musim penghujan. Sari Pediatri 2016;17(5):379-83.
\end{abstract}

Kata kunci: profil, infeksi virus dengue, Sekadau

\section{Profile of Pediatric Patients with Dengue Virus Infection in Sekadau Hospital, Sekadau District, West Kalimantan}

Triswi Widyanti Mugi Raharjanti* Henry Alpius, ${ }^{* *}$ Husnia Auliyatul Umma, ${ }^{*}$ Rustam Siregar*

Background. There is an increase of dengue infection each 10 years cycle with high morbidity and mortality in Sekadau Hospital, West Kalimantan, that bordering to malaysia.

Objective. To describe the profile of dengue infection in clinical spectrum, sex, age, and season.

Method. This study is a descriptive study which was noted by medical record. The subjects are all pediatric patients with dengue infection who were treated in Sekadau hospital, Sekadau District, West Kalimantan in 1 year between April 2014 until March 2015.

Results. From 359 children with dengue infection, there were 41 patients suffered from dengue fever, 306 patients suffered from dengue hemorrhagic fever, and 12 patient suffered from dengue shock syndrome. 182 patients were boys and 177 patients were girls. 132 patients were 0-5 years old group and 227 patients were $>5-18$ years old group. Ninety cases were happened in dry season and 269 cases were happened in rainy season. All cases showed positive NS1.

Conclusion. From 359 subject, the most case is dengue hemorrhagic fever, that happened in boys with the most common age group is $>5-18$ years old, and in rainy season. Sari Pediatri 2016;17(5):379-83.

Keywords: profile, dengue infection, Sekadau

\footnotetext{
Alamat korespondensi: Dr. Husnia Auliyatul Umma, Sp.A. RSUD Dr. Moewardi. Jl Kolonel Sutarto No 132, Surakarta, Jawa Tengah. E-mail: husnia_auliyatul@idai.or.id
} 
I nfeksi dengue yang ditularkan melalui vektor nyamuk Stegomiya aegypty dan Stegomiya albopictus masih merupakan masalah kesehatan global. Di dunia, infeksi dengue berubah cepat secara epidemiologi,. Dalam tiga dekade terakhir di berbagai negara, terjadi peningkatan angka kejadian infeksi dengue yang dapat menimbulkan kematian sekitar kurang dari $1 \%$. Kejadian luar biasa telah sering dilaporkan dari berbagai negara. ${ }^{1}$ Menurut perkiraan WHO, terdapat 2,5 milyar penduduk berisiko untuk terjangkit penyakit dengue, terutama ditemukan di daerah tropis dan subtropis. Setiap tahun, diperkirakan 50 juta manusia terinfeksi virus dengue, $500.000 \mathrm{di}$ antaranya memerlukan rawat inap dan hampir $90 \%$ dari pasien rawat inap adalah anak-anak. ${ }^{1,2}$

Pola epidemiologi infeksi dengue mengalami perubahan dari tahun ke tahun dengan jumlah kasus memuncak setiap siklus 10 tahunan. Selama dua abad terakhir, infeksi dengue terjadi secara endemis di Indonesia dari gejala yang ringan dan self limited disease. Dalam beberapa tahun terakhir, penyakit ini memiliki manifestasi klinis yang semakin berat sebagai demam berdarah dengue (DBD) dan frekuensi kejadian luar biasa meningkat. Indonesia merupakan negara dengan jumlah populasi yang padat dengan hampir $60 \%$ penduduk tinggal di pulau Jawa, daerah kejadian luar biasa infeksi dengue terjadi. Walaupun demikian, penyakit dengue banyak dilaporkan di kota besar dan pedesaan di Indonesia dan telah menyebar sampai di desa-desa terpencil karena perpindahan dan kepadatan penduduk yang tinggi. ${ }^{3,4}$

Pada tahun 2014 di Kabupaten Sekadau provinsi Kalimantan Barat terjadi peningkatan kejadian infeksi dengue yang tajam dibandingkan dengan tahun sebelumnya. Akibatnya, RSUD Sekadau maupun di rumah sakit swasta tidak dapat menampung pasien yang dirawat.

Tujuan dari penelitian ini adalah menggambarkan profil pasien infeksi dengue dengan manifestasi klinis bervariasi, yaitu demam dengue (DD), demam berdarah dengue (DBD), maupun sindrom syok dengue (SSD) yang dirawat di RSUD Sekadau. Dalam kurun waktu satu tahun mulai dari bulan April 2014 sampai dengan Maret 2015, spektrum klinis pasien ditinjau dari jenis kelamin, kelompok usia, hasil pemeriksaan NS1, maupun hubungan dengan musim sehingga bisa dijadikan acuan pengambilan langkah penanggulangan dan pencegahan agar tidak terjadi kejadian luar biasa yang sama di tahun mendatang.

\section{Metode}

Penelitian ini digunakan metode potong lintang deskriptif dengan penelusuran retrospektif. Digunakan data rekam medis pasien selama kurun waktu satu tahun mulai bulan April 2014 sampai dengan bulan Maret 2015. Alasan pemilihan periode waktu karena dalam periode terdapat 2 musim. Musim kemarau terjadi pada bulan April 2014 sampai dengan September 2014 dan penghujan yang terjadi pada bulan Oktober 2014 sampai dengan bulan Maret 2015. Selain itu, karena pada periode tersebut terjadi peningkatan kasus infeksi dengue yang tajam sehingga menimbulkan kejadian luar biasa. Deskripsi kasus infeksi dengue meliputi spektrum manifestasi klinisnya, jenis kelamin, kelompok usia, hasil pemeriksaan NS1, dan hubungan dengan musim. Digambarkan juga hasil pemeriksaan NS1 karena pemeriksaan NS1 merupakan jenis pemeriksaan yang mudah dan tersedia di RSUD Sekadau dan selalu dilakukan pada pasien demam hari pertama sampai kelima tersangka infeksi dengue.

\section{Hasil}

Tabel 1 menggambarkan spektrum manifestasi klinis infeksi dengue, berupa demam dengue (DD), demam berdarah dengue (DBD), dan sindrom syok dengue (SSD) beserta hasil pemeriksaan NS1.

Pada Tabel 2 digambarkan distribusi jenis kelamin pasien infeksi dengue yang dirawat di RSUD Sekadau. Pada Tabel 3 digambarkan distribusi usia pasien infeksi dengue yang dirawat di RSUD Sekadau. Sementara itu, berdasarkan musim, jumlah pasien infeksi dengue pada musim kemarau 90 (25\%) dan penghujan 269 (75\%).

\section{Pembahasan}

Manifestasi klinis infeksi virus dengue sangat luas dan dapat bersifat asimtomatik, demam yang tidak khas, $\mathrm{DD}, \mathrm{DBD}, \mathrm{SSD}$, dan expanded dengue syndrome yang berupa manifestasi klinis yang tidak lazim. ${ }^{2-4}$

Kami mendapatkan gambarann jumlah pasien infeksi dengue beserta distribusi manifestasi klinisnya berupa DD, DBD, atau SSD dan hasil pemeriksaan NS1 yang dilakukan terhadap setiap pasien demam hari pertama sampai kelima tersangka infeksi virus dengue. Pasien dirawat dengan manifestasi klinis infeksi virus 
Triswi Widyanti Mugi Raharjanti dkk: Profil pasien infeksi virus dengue pada anak di RSUD Sekadau

Tabel 1. Manifestasi klinis infeksi virus dengue dan pemeriksaan NS1

\begin{tabular}{lllll}
\hline Bulan & DD (\%) & DBD (\%) & SSD (\%) & NS1 (\%) \\
\hline 2014 & & & & \\
April & 0 & 0 & 0 & 0 \\
Mei & 0 & 0 & 0 & 0 \\
Juni & $3(23)$ & $7(54)$ & $3(23)$ & $13(100)$ \\
Juli & $4(40)$ & $5(50)$ & $1(10)$ & $10(100)$ \\
Agustus & $2(87)$ & $20(87)$ & $1(4)$ & $23(100)$ \\
September & 0 & $43(98)$ & $1(2)$ & $44(100)$ \\
Oktober & $1(1)$ & $87(99)$ & 0 & $88(100)$ \\
November & $16(14)$ & $93(85)$ & $1(1)$ & $110(100)$ \\
Desember & $6(12)$ & $40(83)$ & $2(5)$ & $48(100)$ \\
2015 & & & & \\
Januari & $2(28)$ & $2(28)$ & $3(46)$ & $7(100)$ \\
Februari & $6(50)$ & $6(50)$ & 0 & $12(100)$ \\
Maret & $1(25)$ & $3(75)$ & 0 & $4(100)$ \\
Total & $41(11)$ & $306(85)$ & $12(4)$ & $359(100)$ \\
\hline
\end{tabular}

Tabel 2. Distribusi jenis kelamin

\begin{tabular}{lcc}
\hline Bulan & Laki-laki (\%) & Perempuan (\%) \\
\hline 2014 & & \\
April & 0 & 0 \\
Mei & 0 & 0 \\
Juni & $10(77)$ & $3(23)$ \\
Juli & $6(60)$ & $4(40)$ \\
Agustus & $10(43)$ & $13(57)$ \\
September & $26(59)$ & $18(41)$ \\
Oktober & $37(42)$ & $51(89)$ \\
November & $56(51)$ & $54(49)$ \\
Desember & $26(54)$ & $22(46)$ \\
2015 & & \\
Januari & $3(43)$ & $4(57)$ \\
Februari & $7(58)$ & $5(42)$ \\
Maret & $1(25)$ & $3(75)$ \\
Total & $182(51)$ & $177(49)$ \\
\hline
\end{tabular}

dengue dengan hasil NS1 positif, kemudian diobservasi secara klinis dan laboratoris. Dalam perawatan pasien selanjutnya ditentukan diagnosis apakah menderita DD, DBD, atau SSD. ${ }^{6}$

Selama periode satu tahun, kami mendapatkan 359 pasien anak dirawat di RSUD Sekadau dengan infeksi dengue. Jumlah ini terbagi menjadi 41 (11\%) DD, 306 (85\%) DBD, dan 12 (4\%) pasien SSD. Semua pasien tersebut menunjukkan hasil NS1 positif. Manifestasi klinis infeksi virus dengue didominasi oleh DBD. Jumlah pasien DD yang dirawat paling
Tabel 3. Distribusi usia

\begin{tabular}{lcc}
\hline Bulan & $0-5$ tahun $(\%)$ & $>5-18$ tahun $(\%)$ \\
\hline 2014 & & \\
April & 0 & 0 \\
Mei & 0 & 0 \\
Juni & $3(23)$ & $10(73)$ \\
Juli & $3(30)$ & $7(70)$ \\
Agustus & $4(17)$ & $19(83)$ \\
September & $2(5)$ & $42(95)$ \\
Oktober & $32(36)$ & $56(64)$ \\
November & $53(48)$ & $55(52)$ \\
Desember & $21(44)$ & $27(56)$ \\
2015 & & \\
Januari & $2(29)$ & $5(71)$ \\
Februari & $8(67)$ & $4(33)$ \\
Maret & $2(50)$ & $2(50)$ \\
Total & $132(37)$ & $227(63)$ \\
\hline
\end{tabular}

sedikit karena manifestasi klinisnya seringkali ringan dan pasien hanya berobat jalan dengan diagnosis akhir yang tidak diketahui atau diketahui, tetapi sembuh spontan dengan perawatan di rumah. Jumlah pasien SSD juga sedikit karena sebagian besar pasien berobat dan dirawat saat awal demam sehingga sudah diberikan cairan dan dilakukan pengawasan ketat sehingga tidak terjadi syok. Karyanti $\mathrm{dkk}^{7}$ melaporkan angka kejadian DBD di Indonesia meningkat dari tahun ke tahun, tetapi berbanding terbalik dengan angka kematian yang menurun. 
Metode pemeriksaan NS1 digunakan untuk mendeteksi antigen flavivirus yang sudah tersedia di RSUD Sekadau dan dilakukan terhadap setiap pasien demam hari pertama sampai kelima dengan dugaan infeksi dengue. Semua pasien yang dirawat dengan infeksi virus dengue menunjukkan hasil NS1 yang positif. Hal tersebut menunjukkan pemeriksaan NS1 cukup efektif untuk mendeteksi adanya infeksi flavivirus, tetapi tidak spesifik menunjukkan jenis virus. Dengan demikian, manifestasi klinis digunakan untuk menentukan apakah pasien mengalami DD, DBD, atau SSD yang memerlukan pemeriksaan lanjutan serologi $\operatorname{IgM}$ ataupun $\operatorname{IgG}$ anti dengue. ${ }^{8-10}$

Selama periode satu tahun, kami mendapatkan 359 jumlah pasien infeksi virus dengue, 182 (51\%) lakilaki dan 177 (49\%) perempuan. Jumlah pasien infeksi virus dengue lebih banyak anak laki-laki dibandingksn perempuan. Temuan tersebut tidak berbeda jauh dengan penelitian Hartoyo ${ }^{4}$ yang melaporkan $123(54,6 \%)$ kasus jumlah pasien laki-laki dan 66 perempuan $57(45,4$. Hasil tersebut juga hampir sama dengan laporan penelitian di bagian IKA RSCM yang mendapatkan perbandingan laki-laki dan perempuan 1,3:1 Kami mendapatkan perbandingan laki-laki perempuan adalah 1,03:1. Keadaan tersebut kemungkinan berkaitan dengan kebiasasan nyamuk Stegomiya aegypti dan Stegomiya albopictus yang aktif menggigit pada siang hari dengan dua puncak aktivitas, yaitu pada pukul 08.00-12.00 dan 15.00-17.00. Pada jam tersebut anak bermain di luar rumah, dan anak laki-laki lebih sering bermain di luar rumah dibandingkan perempuan. Selain itu, terdapat keadaan pembentukan IgM anti dengue lebih mudah terjadi pada anak laki-laki dengan mekanisme yang belum diketahui. ${ }^{4,11}$

Selama periode satu tahun kami mendapatkan, dari 359 pasien, terdapat $132(37 \%)$ pada kelompok usia 0-5 tahun dan 227 (63\%) pada kelompok usia >5 tahun-18 tahun. Hasil tersebut mirip dengan penelitian Hartoyo, ${ }^{4}$ dari bagian IKA Universitas Lambung Mangkurat pada tahun 2008 yang melaporkan insiden tertinggi infeksi virus dengue terjadi pada kelompok usia 5-9 tahun. Penelitian lain yang dilakukan di Indonesia, Karyanti $\mathrm{dkk}^{7}$ melaporkan bahwa dalam periode 45 tahun terjadi peningkatan rata-rata usia insiden DBD di atas 5-14 tahun pada tahun 1999 dan seterusnya. Hal tersebut kemungkinan berkaitan dengan kelompok usia $>5$ tahun-18 tahun adalah kelompok usia sekolah yang beraktifitas di luar rumah pada jam nyamuk menggigit. Di samping itu, potensi penularan lebih tinggi karena aktivitas anak banyak di tempat dengan kepadatan tinggi. ${ }^{4,6}$

Berdasarkan musim, dari 359 pasien infeksi virus dengue ternyata $90(25 \%)$ kasus terjadi pada musim kemarau dan 269 (75\%) pada musim penghujan. Kasus terbanyak pada musim penghujan karena banyaknya penampungan air yang menjadi tempat nyamuk vektor berkembangbiak. $^{3}$

\section{Kesimpulan}

Infeksi virus dengue merupakan masalah kesehatan masyarakat karena morbiditasnya tinggi. Manifestasi klinis terbanyak pada pasien yang dirawat di RSUD Sekadau adalah DBD, dengan distribusi jenis kelamin terbanyak anak laki-laki, kelompok umur $>5$ tahun-18 tahun, dan pada musim penghujan.

\section{Daftar pustaka}

1. Karyanti MR, Hadinegoro SR. Perubahan epidemiologi demam berdarah dengue di Indonesia. Sari Pediatri 2009; 10:424-32.

2. Hadinegoro SR. Manifestasi klinis dan perjalanan penyakit infeksi virus dengue. Dalam: Hadinegoro SR, Moedjito I, Chairulfatah A, penyunting. Pedoman diagnosis dan tata laksana infeksi virus dengue pada anak. Edisi pertama. Jakarta. IDAI;2014. h.13-31.

3. Candra A. Demam berdarah dengue: epidemiologi, patogenesis, dan faktor risiko penularan. Aspirator 2010;2:110-9.

4. Hartoyo E. Spektrum klinis demam berdarah dengue pada anak. Sari Pediatri 2008;10:145-50.

5. PPSP (percepatan pembangunan sanitasi lingkungan). Buku putih sanitasi Pokja Sanitasi Kabupaten Sekadau tahun 2013. Sekadau: PPSP; 2013.

6. Wakimoto, Camacho, Guaraldo, Damasceno, Brasil. Dengue in children: a systematic review of clinical and laboratory factor associated with severity. Espert Rev Anti Infect Ther 2015;13:1441-56.

7. Karyanti MR, Uiterwaal CSPM, Kusriastuti R, Hadinegoro SR, Rovers MM, Heesterbeek H, dkk. The changing incidence of dengue haemorrhagic fever in Indonesia: a 45-year registry-based analysis. BMC Infect Dis 2014;14:1-7.

8. Malhi TH, Khan AH, Adnan AS, Sarriff A, Khan YH, Jummaat. Clinico-laboratory spectrum of dengue 
viral infection and risk factors associated with dengue hemorrhagic fever: a retrospective study. BMJ Infect Dis 2015;15:1141-3.

9. Halstead SB. Dengue fever and dengue hemorrhagic fever. Dalam: Kliegmann RM, Stanton BF, St Geme JW, Schor NF, penyunting. Nelson textbook of pediatrics. Edisi 20. Philadelphia: Elsevier;2016.h.1629-32.

10. Sjahrodji, Azhali Manggus. Infeksi virus dengue.
Dalam: Garna HH, penyunting. Buku ajar divisi infeksi dan penyakit tropis. Edisi I. Jakarta;Sagung Seto; 2012.h.335-62

11. Setiati TE, Mairuhu ATA, Koraka P, Supriana M, Mac Gillavri MR, Brandjes DPM, dkk. Dengue disease severity in Indonesian childres: an evaluation of the world health organization classification system. BMJ Infect Dis 2007;7:1-8. 